\title{
Optical and Electrical Properties of Antimony and Fluorine Doped Tin Oxide Thin Films
}

\author{
Saw Lin Oo ${ }^{1}$, Zayar Thu ${ }^{2}$, Than Zaw Oo ${ }^{3}$, Pho Kaung, \\ ${ }^{1}$ Department of Physics, University of East Yangon, Myanmar \\ ${ }^{2}$ Department of Physics, Maubin University, Myanmar \\ ${ }^{3}$ Department of Physics, Panglong University, Myanmar \\ ${ }^{4}$ University of Yangon, Myanmar
}

Copyright $(2017$ by authors, all rights reserved. Authors agree that this article remains permanently open access under the terms of the Creative Commons Attribution License 4.0 International License

\begin{abstract}
The $\mathrm{Sb}: \mathrm{F}: \mathrm{SnO}_{2}$ layers (AR) were prepared by spray pyrolysis method. The anti-reflective layers (AR) heat-treated at $500^{\circ} \mathrm{C}$ for $30 \mathrm{~min}$ (solution amount $20 \mathrm{cc}$ and $25 \mathrm{cc}$ ) have shown an improved crystallinity with crystallite size of 38-39 nm, high optical transmission of around $70 \%$ at $450 \mathrm{~nm}$. Incorporation of anti-reflective layer at cathode interface of $\mathrm{SiO}_{2} / \mathrm{Si}(\mathrm{N})$ devices increased the power conversion efficiency from $1.2 \%$ to $2.7 \%$ which is mainly contributed from photocurrent enhancement. The enhanced efficiency mainly contributed to the increase in $\mathrm{J}_{\mathrm{sc}}$. It is attributed to enhanced light absorption and better charge transport in the $\mathrm{SiO}_{2} / \mathrm{Si}(\mathrm{N})$ device with $\mathrm{Sb}: \mathrm{F}: \mathrm{SnO}_{2}$ AR layer. Results of optical and electrical studies show that the films are well suited for thin film solar cell as a window layer.
\end{abstract}

Keywords Anti-reflective Layer (AR), Antimony and Fluorine Doped Tin Oxide (Sb:F:SnO $\left.{ }_{2}\right)$

\section{Introduction}

In order to enhance the performance of a solar cell, it needs to reduce the reflection loss from the surface of the cell [1]. A flexible optical design for light collection is vital in achieving high performance solar cells. An ideal anti-reflective (AR) structure leads to zero reflection loss on solar cell surfaces over an extended solar spectral range for all angles of incidence. Thus, the perfect anti-reflective structure has been a subject of intensive research in thin film optics and most importantly, for solar cell applications [2].The interfacial layer in a Schottky barrier solar cell plays an important role in determining the short circuit current, open circuit voltage, fill factor and efficiency of the cell. The effects of interfacial oxide layer thickness on the open circuit voltage and efficiency of the cells have been increased [3]. Aluminum ( $\mathrm{Al})$ and Silver (Ag) metal layers were used in place of the counter and back electrodes $[1,4]$. Among these,
$\mathrm{Sb}: \mathrm{F}: \mathrm{SnO}_{2}$ is chosen as an anti-reflective (AR) layer because of its high electrical conductivity and its transparency in the visible and infrared light $[5,6]$. Further, its refractive index lies in between 1.7 and 2.0 and hence it can be used as an antireflection (AR) coating [7]. In addition, $\mathrm{Sb}: \mathrm{F}: \mathrm{SnO}_{2}$ layer provides both high optical transmittance and high electrical conductivity simultaneously. The sol-gel processing exhibits good uniformity and better-controlled composition for thin film deposition by the spinning or spray pyrolysis method $[6,8]$. In this study, an attempt is made to find the effect of different layers on its optical and electrical properties by simultaneously doping antimony and fluorine. In addition, the effect of an anti-reflective layer on the photovoltaic efficiency of $\mathrm{SiO}_{2} / \mathrm{Si}$ solar cells is also highlighted.

\section{Materials and Methods}

\subsection{Substrate Cleaning}

The substrate cleaning is very important in the deposition of thin films. The substrates used in this work were phosphor doped N-type silicon with the resistivity value of $0.01 \sim 10 \Omega \mathrm{cm}$ and orientation of (100) plane. The Si substrate was cut into the dimension of 1 " $\mathrm{x} 1$ ". Firstly the substrate was cleaned with $\mathrm{HF}: \mathrm{H}_{2} \mathrm{O}(1: 5)$ for 10 minutes to remove native oxide and immersed in acetone for 10 minutes. Then the substrate was immersed in methyl alcohol for 10 minutes to remove the impurities. After that, it was rinsed with deionized water (DI water) for a few minutes and dried with nitrogen blow at room temperature $[9,10]$.

\subsection{Deposition of Sb:F:SnO 2 Film}

The $\mathrm{Sb}: \mathrm{F}: \mathrm{SnO}_{2}$ thin films were prepared as per synthesis route shown in Figure 1. The $\mathrm{SnCl}_{4} .5 \mathrm{H}_{2} \mathrm{O}$ (98\% purity), $\mathrm{SbCl}_{3}$ (99\% purity), and $\mathrm{NH}_{4} \mathrm{~F}$ (98\% purity) were used as 
precursors. $\mathrm{SnCl}_{4} .5 \mathrm{H}_{2} \mathrm{O}(10 \mathrm{~g})$ was dissolved in ethanol $(80 \mathrm{ml})$ at room temperature under stirring. On the other hand, $2 \mathrm{~g}$ of $\mathrm{NH}_{4} \mathrm{~F}$ was dissolved in $10 \mathrm{ml}$ deionized water and $3 \mathrm{~g}$ of antimony trichloride $\left(\mathrm{SbCl}_{3}\right)$ was separately dissolved in ethanol $(20 \mathrm{ml})$. Over a period of exactly 10 minutes, $\mathrm{NH}_{4} \mathrm{~F}$ solution and $\mathrm{SbCl}_{3}$ solution were added to the $\mathrm{SnCl}_{4} \cdot 5 \mathrm{H}_{2} \mathrm{O}$ solution. The mixture solution was continuously stirred for 12 hours at $60^{\circ} \mathrm{C}$ by solochemical method. Solution became transparent and filtered by $0.45 \mu \mathrm{m}$ pole size filters. The clear solution of $20 \mathrm{cc}, 25 \mathrm{cc}$ and $30 \mathrm{cc}$ were used to make anti-reflective $\left(\mathrm{Sb}: \mathrm{F}: \mathrm{SnO}_{2}\right)$ layers with working distance of about $20 \mathrm{~cm}$ and angle of $90^{\circ}$ by spray pyrolysis method. The substrates temperature was kept at $500^{\circ} \mathrm{C}$ and monitored by digital temperature controller. Finally, the films were annealed at $500^{\circ} \mathrm{C}$ for 30 minutes and measured for their optical and electrical properties $[1,11]$.

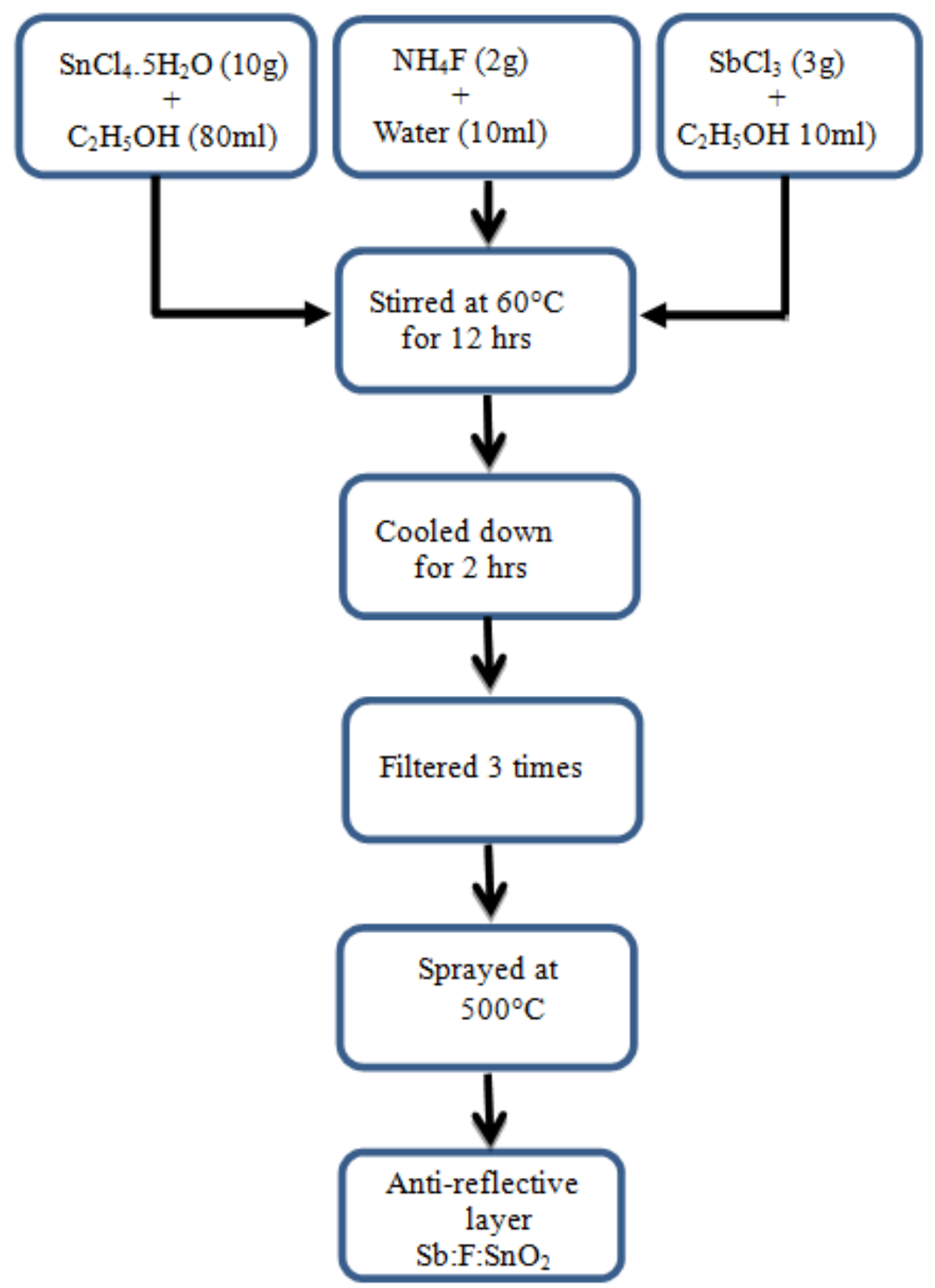

Figure 1. The synthesis route of anti-reflective layer 


\section{Results and Discussion}

\subsection{Structural Properties of Sb:F:SnO $\mathbf{S}_{2}$ Films}

Structural studies of $\mathrm{Sb}: \mathrm{F}: \mathrm{SnO}_{2}$ films with solution amount of $20 \mathrm{cc}, 25 \mathrm{cc}$ and $30 \mathrm{cc}$ heat-treated at $500^{\circ} \mathrm{C}$ for 30 minutes were done using X-ray diffraction (XRD) technique. The crystalline sharp peaks in the diffraction patterns were identified by using the International Centre for Diffraction Data (ICDD). The crystalline size was calculated by using Scherer's equation; $\mathrm{D}=(\mathrm{k} \lambda) /(\mathrm{B} \cos \theta)$ where, $\mathrm{B}$ is the peak width measured at half intensity (radian), $\lambda$ is the wavelength measured in $\AA, \mathrm{k}$ is the particle shape factor or Scherer constant $(\mathrm{k}=0.9)$ and $\mathrm{D}$ is the diameter of the crystallites $(\AA)$.

The XRD spectra for $\mathrm{Sb}: \mathrm{F}: \mathrm{SnO}_{2}$ films with $20 \mathrm{cc}, 25 \mathrm{cc}$ and $30 \mathrm{cc}$ are depicted in Figure 2. XRD diffraction peaks belonging to (110), (101), (200), (211) and (301) were observed in all the $\mathrm{Sb}: \mathrm{F}: \mathrm{SnO}_{2}$ films which are well matched with the powder diffraction data of 77-0447> Cassiterite, syn- $\mathrm{SnO}_{2}, 88-2348>\mathrm{Sn} .918 \mathrm{Sb} .109 \mathrm{O}_{2}$ - Tin Antimony Oxide and $70-0164>\mathrm{SnF}_{2}-\mathrm{Tin}$ Fluoride. For the samples using $20 \mathrm{cc}$ and $25 \mathrm{cc}$ solution amount, the diffraction peaks were pronounced sharper indicating that the crystallinity of $\mathrm{Sb}: \mathrm{F}: \mathrm{SnO}_{2}$ was improved at this processing condition. The average crystallite sizes estimated by using Scherer's equation were found to be $38.5 \mathrm{~nm}, 39.3 \mathrm{~nm}$ and $50.9 \mathrm{~nm}$ respectively for $\mathrm{Sb}: \mathrm{F}: \mathrm{SnO}_{2}(20 \mathrm{cc}, 25 \mathrm{cc}$ and $30 \mathrm{cc})$. The $\mathrm{Sb}: \mathrm{F}: \mathrm{SnO}_{2}$ has tetragonal structure with a-axis value of $4.7441 \AA$ and c-axis value of $3.1959 \AA$...

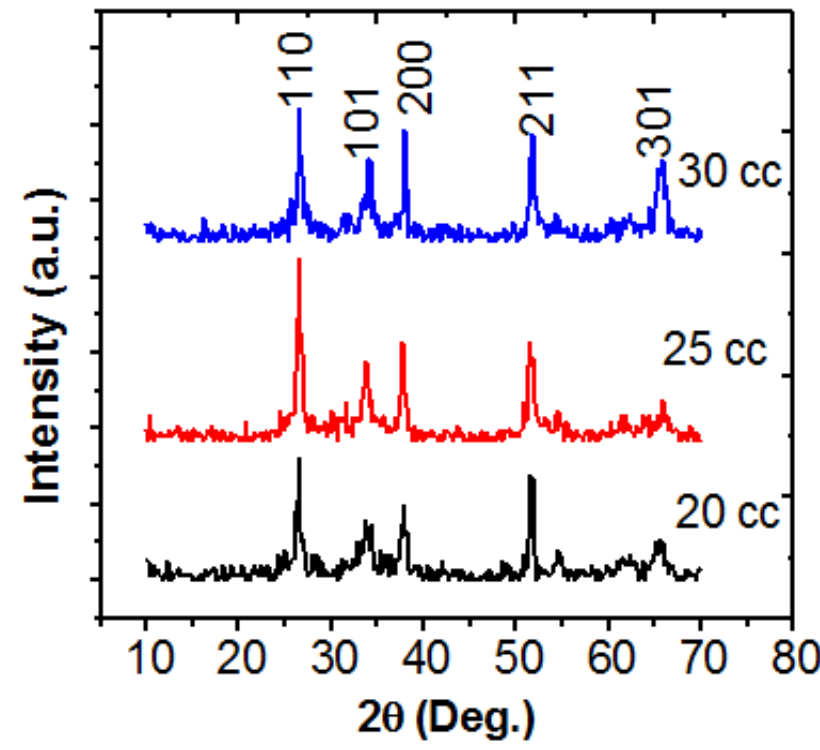

Figure 2. The $\mathrm{XRD}$ spectra for $\mathrm{Sb}: \mathrm{F}: \mathrm{SnO}_{2}$ films using different solution amounts (20cc, $25 \mathrm{cc}$ and $30 \mathrm{cc}$ ).

\subsection{Surface Morphology of Sb:F:SnO $\mathrm{Silms}_{2}$}

Surface morphology of $\mathrm{Sb}: \mathrm{F}: \mathrm{SnO}_{2}$ were examined by scanning electron microscopy (SEM). Figure 3 shows the SEM images of $\mathrm{Sb}: \mathrm{F}: \mathrm{SnO}_{2}$ films (solution amount $30 \mathrm{cc}$ ). It is observed that the $\mathrm{Sb}: \mathrm{F}: \mathrm{SnO}_{2}$ films were fully covered on the substrate and the particle-like features with submicron size ranging from $0.2 \mu \mathrm{m}$ to $0.5 \mu \mathrm{m}$ were mostly found on the film surface.
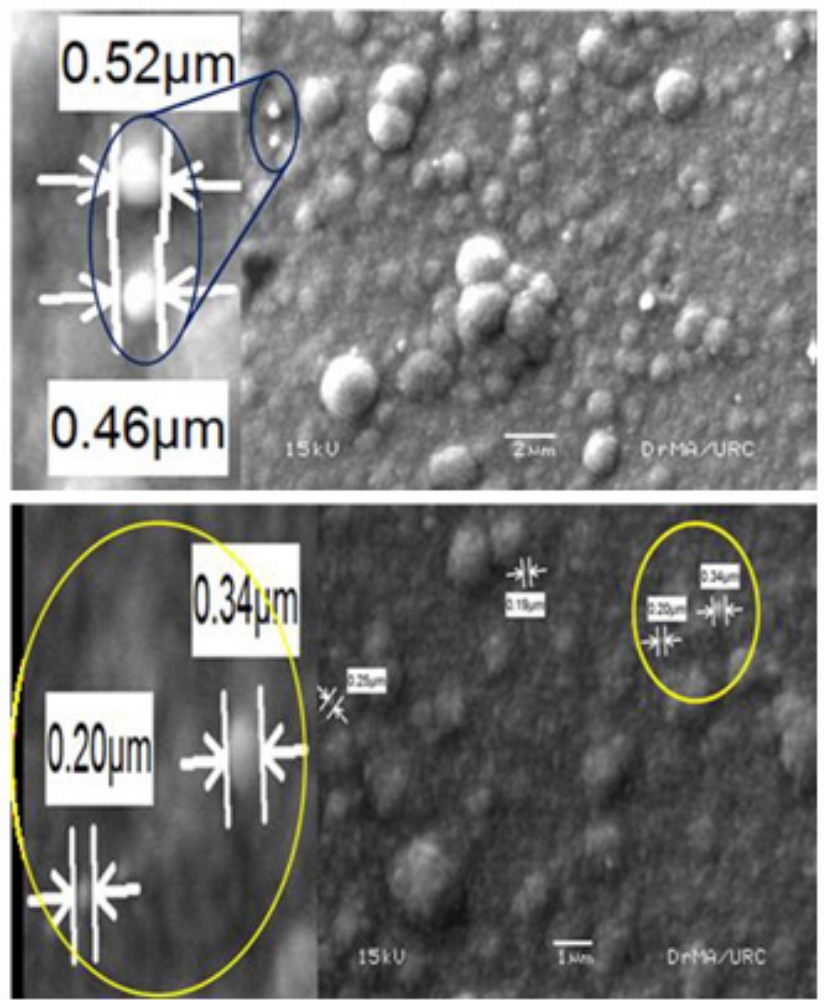

Figure 3. The SEM micrographs of $\mathrm{Sb}: \mathrm{F}: \mathrm{SnO}_{2}$ films prepared from solution amount of $25 \mathrm{cc}$. Magnification: $5500 \mathrm{x}$ (upper) and 10000x (lower)

\subsection{Optical Properties}

The optical transmission spectra of $\mathrm{Sb}: \mathrm{F}: \mathrm{SnO}_{2}$ films using solution amount of $20 \mathrm{cc}, 25 \mathrm{cc}$ and $30 \mathrm{cc}$ were recorded in the wavelength of 300 to $800 \mathrm{~nm}$ using Shimadzu UV-1800 spectrophotometer. The transmission spectra of $\mathrm{SnO}_{2}: \mathrm{F}: \mathrm{Sb}$ layers were shown in Figure 4-a. The transmittance value of $40 \%$ to $70 \%$ was found in the visible region of $400-700 \mathrm{~nm}$. As clearly seen, the optical transmittance decreased (absorption increased) upon increasing solution amount which is ascribed to thicker film formation with higher solution amount. The thickness of the films was determined by surface profiler (Tencor Alpha step IQ) and the values are listed in Table 1. In addition, the optical band gaps of $\mathrm{SnO}_{2}: \mathrm{F}: \mathrm{Sb}$ anti-reflective layers were estimated from the plot of $(\alpha h v)^{2}$ versus hv as shown in Figure 4-b. The extrapolation of the linear region of the plot toward $\mathrm{x}$-axis provides the optical band gap energy value. The band gap energy was found to be $3.0 \mathrm{eV}, 3.4 \mathrm{eV}$ and $3.8 \mathrm{eV}$ for $20 \mathrm{cc}$, $25 \mathrm{cc}$ and $30 \mathrm{cc}$ respectively. Higher optical transmission and wider band gap energy are preferred for interlayer (anti-reflective layer) in solar cells.

The refractive index (n) of each and every layer in multilayer solar cells is a key parameter which can determine the optical electric field distribution and absorption of the solar cell. The refractive index of $\mathrm{Sb}: \mathrm{F}: \mathrm{SnO}_{2}$ layer $(20 \mathrm{cc})$ 
was determined by spectroscopic ellipsometer (J.A. Woolam Co. Inc M-44). Figure 4-c depicts the plot of refractive index versus wavelength. The incident angle of $75.2^{\circ}$ was used and the data was fit using Cauchy model. The refractive index of $\mathrm{Sb}: \mathrm{F}: \mathrm{SnO}_{2}$ layer was found to be 1.8 corresponding to the wavelength $580 \mathrm{~nm}$ for all $\mathrm{SnO}_{2}: \mathrm{F}: \mathrm{Sb}$ films.

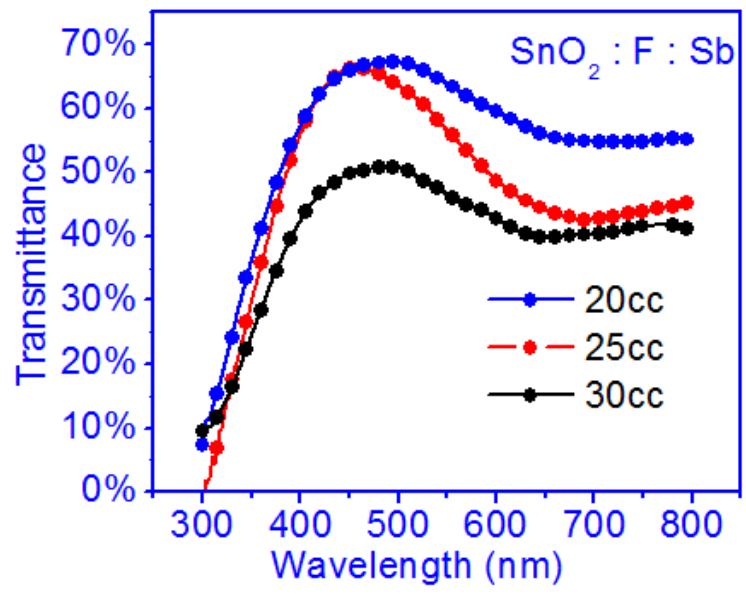

(a)

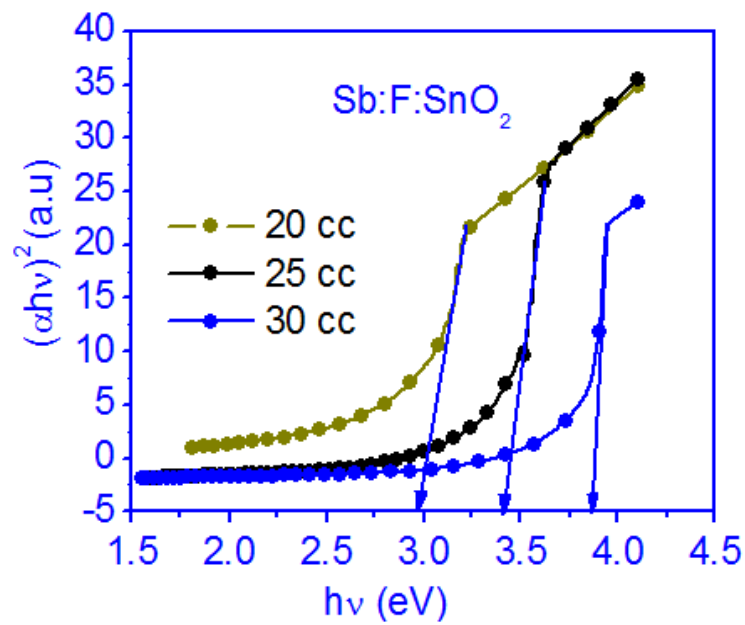

(b)

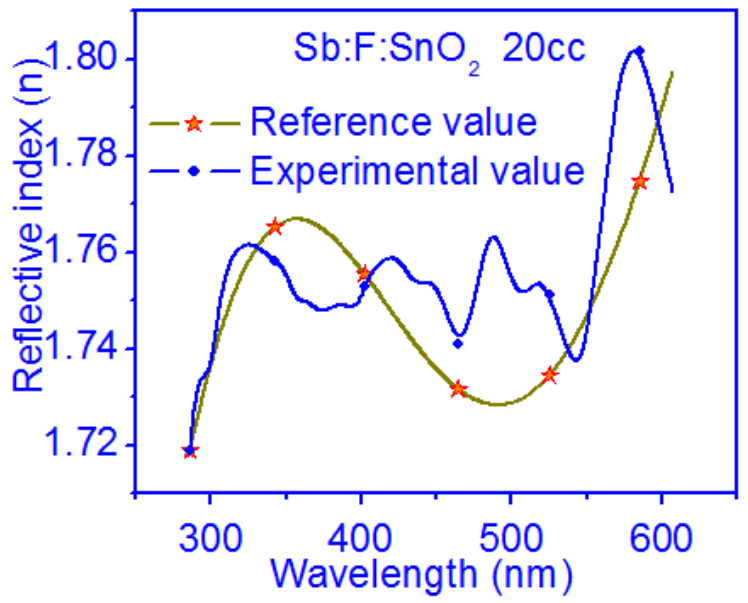

(c)

Figure 4. (a) Optical transmission spectra, (b) plot of $(\alpha \mathrm{hv})^{2}$ versus hv for $\mathrm{Sb}: \mathrm{F}: \mathrm{SnO}_{2}$ films (solution amount of $20 \mathrm{cc}, 25 \mathrm{cc}$ and $30 \mathrm{cc}$ ) and (c) plot of refractive index vs. wavelength for $\mathrm{Sb}: \mathrm{F}: \mathrm{SnO}_{2}$ film $(20 \mathrm{cc})$.
Table 1. The refractive index, film thickness and optical band gap energy of $\mathrm{Sb}: \mathrm{F}: \mathrm{SnO}_{2}$ films.

\begin{tabular}{|c|c|c|c|c|}
\hline $\begin{array}{c}\text { Volume of } \\
\text { Spray } \\
\text { solution (cc) }\end{array}$ & $\begin{array}{c}\text { Refractive } \\
\text { index }\end{array}$ & $\begin{array}{c}\text { Thickness } \\
(\mathrm{nm})\end{array}$ & $\operatorname{Eg}(\mathrm{eV})$ & $\begin{array}{c}\text { Resistance } \\
(\Omega)\end{array}$ \\
\hline 20 & 1.8 & 63.9 & 3.0 & 85.6 \\
\hline 25 & 1.8 & 103.2 & 3.4 & 45.6 \\
\hline 30 & 1.8 & 122.9 & 3.8 & 30.2 \\
\hline
\end{tabular}

\subsection{Electrical Properties of Sb:F:SnO $\mathrm{Silms}_{2}$}

Electrical conductivity (mobility) of anti-reflective layer is also important to be measured since it would determine the chare transport. The electrical resistance values of $\mathrm{Sb}: \mathrm{F}: \mathrm{SnO}_{2}$ films were measured by using digital multimeter and are listed in Table 1. The electrical resistance increased with increasing film thickness.

\subsection{Impact of $\mathrm{Sb}: \mathrm{F}: \mathrm{SnO}_{2}$ Anti-reflective Layers on Photocurrent Generation}

The $\mathrm{Sb}: \mathrm{F}: \mathrm{SnO}_{2}$ anti-reflective layer has been integrated at the cathode interface of the $\mathrm{Si} / \mathrm{SiO}_{2}$ photovoltaic device. Figure 5 shows the schematic diagram of $\mathrm{SiO}_{2} / \mathrm{Si}(\mathrm{N})$ device with and without anti-refractive layer together with their photographs. Figure 6 shows the current-voltage (I-V) characteristics of $\mathrm{SiO}_{2} / \mathrm{Si}(\mathrm{N})$ photovoltaic device with and without anti-reflective layer. The critical parameters for the device with and without anti-reflective layer are listed in Table (2).

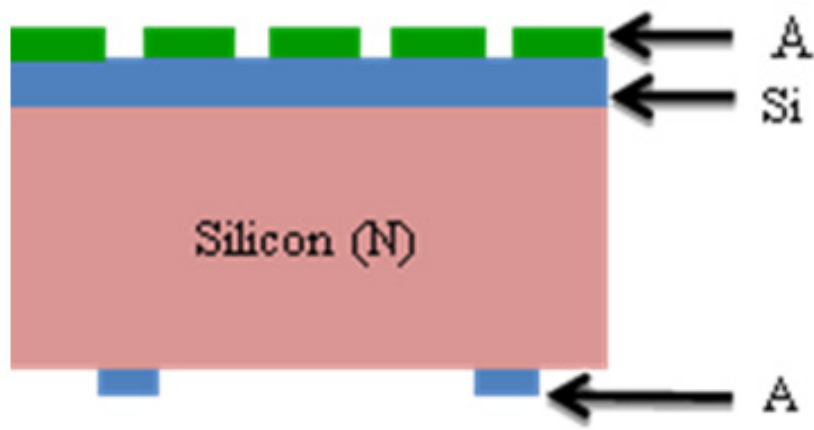

(a)

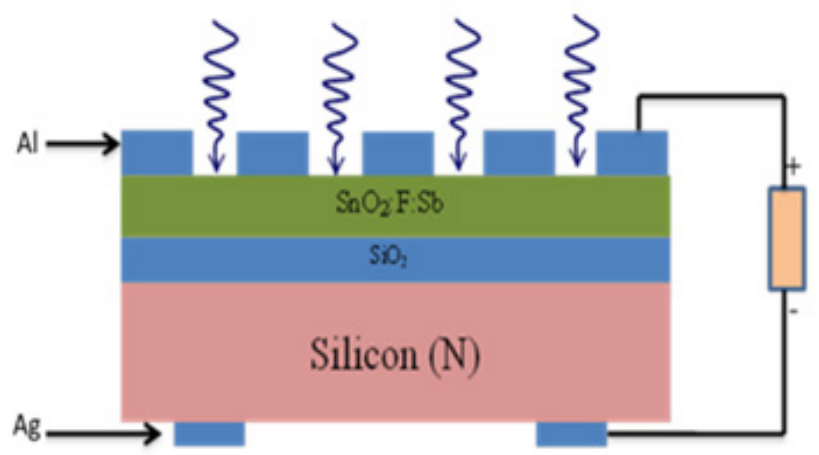

(b) 


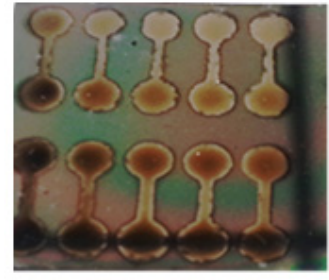

(a) $\mathrm{Si} / \mathrm{SiO}_{2} / \mathrm{AR}$

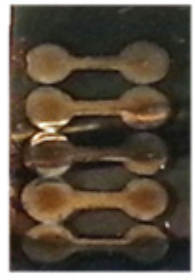

(b) $\mathrm{Si} / \mathrm{SiO}_{2} / \mathrm{AR}$

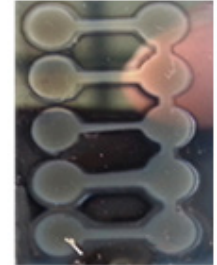

(c) $\mathrm{Si} / \mathrm{SiO} 2$ (c)

Figure 5. Schematic diagram of $\mathrm{SiO}_{2} / \mathrm{Si}(\mathrm{N})$ device (a) without anti-reflective layer and (b) with anti-reflective layer and (c) Photographs of the $\mathrm{SiO}_{2} / \mathrm{Si}(\mathrm{N})$ devices.

The reference device without anti-reflective layer provided the short-circuit current density $\left(\mathrm{J}_{\mathrm{sc}}\right)$ of $71.28 \mathrm{~mA} / \mathrm{cm}^{2}$, open circuit voltage $\left(\mathrm{V}_{\text {oc }}\right)$ of $4.4 \mathrm{mV}$ and fill factor $(\mathrm{FF})$ of 0.38 yield power conversion efficiency (PCE) of $1.2 \%$ under light source $100 \mathrm{mWcm}^{-2}$. Upon integrating anti-reflective layer $\left(\mathrm{Sb}: \mathrm{F}: \mathrm{SnO}_{2} 20 \mathrm{cc}\right.$ and $\left.25 \mathrm{cc}\right)$ at the cathode interface of the device, the $\mathrm{J}_{\mathrm{sc}}$ increased from $71.28 \mathrm{~mA} / \mathrm{cm}^{2}$ to $81.14 \mathrm{~mA} / \mathrm{cm}^{2}$ and $90 \mathrm{~mA} / \mathrm{cm}^{2}$ and $\mathrm{FF}$ from 0.38 to 0.56 and $0.60, \mathrm{~V}_{\text {oc }}$ from $4.4 \mathrm{mV}$ to $4.7 \mathrm{mV}$ and $5.0 \mathrm{mV}$ and power conversion efficiency increased from $1.20 \%$ to $2.15 \%$ and $2.70 \%$ respectively for the $\mathrm{SiO}_{2} / \mathrm{Si}(\mathrm{N})$ device with Sb:F: $\mathrm{SnO}_{2}$ AR layer $(20 \mathrm{cc}$ ad $25 \mathrm{cc}$ ). The enhanced efficiency mainly contributed to the increase in $\mathrm{J}_{\mathrm{sc}}$. The increased $\mathrm{J}_{\mathrm{sc}}$ is attributed to enhanced light absorption and better charge transport in the $\mathrm{SiO}_{2} / \mathrm{Si}(\mathrm{N})$ device with $\mathrm{Sb}: \mathrm{F}: \mathrm{SnO}_{2} \mathrm{AR}$ layer.

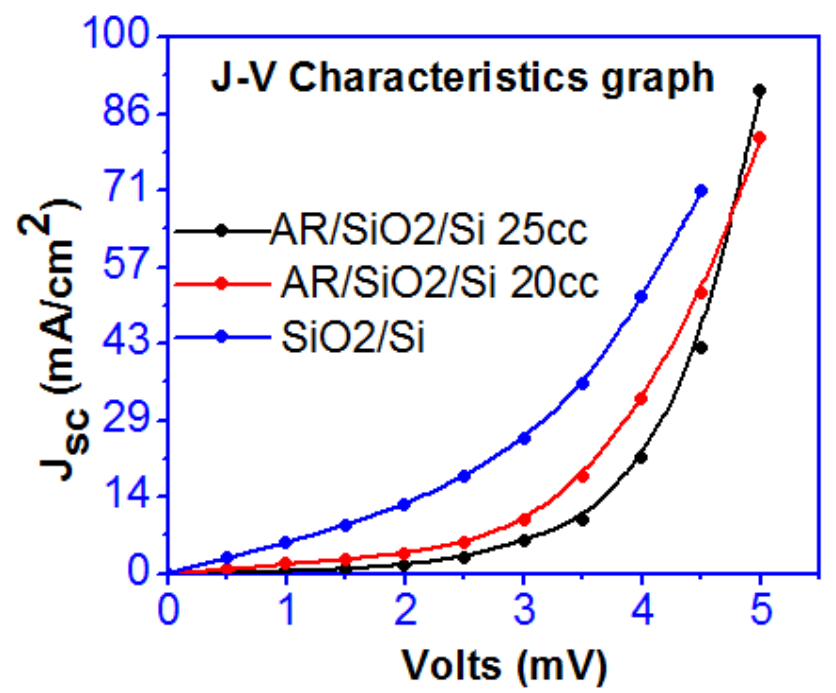

Figure 6. I-V characteristics of $\mathrm{SiO}_{2} / \mathrm{Si}(\mathrm{N})$ photovoltaic device with and without anti-reflective layers

Table 2. The critical device parameters of $\mathrm{SiO}_{2} / \mathrm{Si}(\mathrm{N})$ device with and without Anti-reflective (AR) layer.

\begin{tabular}{|c|c|c|c|c|}
\hline Devices & $\mathrm{J}_{\mathrm{sc}}\left(\mathrm{mAcm}^{-2}\right)$ & $\mathrm{FF}$ & $\mathrm{V}_{\mathrm{oc}}(\mathrm{mV})$ & PCE (\%) \\
\hline Without AR layer & 71.28 & 0.38 & 4.4 & 1.20 \\
\hline $\begin{array}{c}\text { With AR layer } \\
(20 \mathrm{cc})\end{array}$ & 81.14 & 0.56 & 4.7 & 2.15 \\
\hline $\begin{array}{c}\text { With AR layer } \\
(25 \mathrm{cc})\end{array}$ & 90.00 & 0.60 & 5.0 & 2.70 \\
\hline
\end{tabular}

\section{Conclusions}

The $\mathrm{Sb}: \mathrm{F}: \mathrm{SnO}_{2}$ layers (AR) were prepared by spray pyrolysis method. The anti-reflective layers (AR) (solution amount $20 \mathrm{cc}$ and $25 \mathrm{cc}$ ) have shown an improved crystallinity with crystallite size of 38-39 nm, high optical transmission of $70 \%$ at $450 \mathrm{~nm}$. Incorporation of anti-reflective layer at cathode interface of $\mathrm{SiO}_{2} / \mathrm{Si}(\mathrm{N})$ devices increased the power conversion efficiency from $1.2 \%$ to $2.7 \%$ which is mainly contributed from photocurrent enhancement. The enhanced efficiency mainly contributed to the increase in $J_{\mathrm{sc}}$. It is attributed to enhanced light absorption and better charge transport in the $\mathrm{SiO}_{2} / \mathrm{Si}(\mathrm{N})$ device with $\mathrm{Sb}: \mathrm{F}: \mathrm{SnO}_{2}$ AR layer. Results of optical and electrical properties show that the films are well suited for window layer on thin films solar cells.

\section{Acknowledgements}

The author (SLO) thanks Organizing Committee of the $4^{\text {th }}$ International Conference on Applied Engineering Physics for their kind invitation to present this research work.

\section{REFERENCES}

[1] D. Hocine, M.S. Belkaïd, and K. Lagha, "Influence of interfacial oxide layer thickness on conversion efficiency of $\mathrm{SnO} 2 / \mathrm{SiO} 2 / \mathrm{Si}$ (N) Solar Cells," Rev. des Energies Renouvelables, vol. 11(3), pp. 379-384, 2008.

[2] L.Chinnappa, K. Ravichandran and B. Sakthivel,"Investigation on Doubly Doped (Fluorine + Antimony) Tin Oxide Films Deposited by a Simplified Spray Pyrolysis Technique" Pro. Indian Natn. Sci. Acad. vol.79(3), pp. 409-415, 2013.

[3] D. Hocine and M.S. Belkaid, "Effects of interfacial oxide layer thickness and interface states on conversion efficiency of $\mathrm{SnO}_{2} / \mathrm{SiO}_{2} / \mathrm{Si}(\mathrm{N})$ solar cells" $R E \& P Q J$ vol. 1(6), pp. 170-174, 2008.

[4] M.A. Muhsien, E.T. Salem, and I.R. Agool, "Preparation and characterization of $\left(\mathrm{Au} / \mathrm{n}-\mathrm{SnO}_{2} / \mathrm{SiO}_{2} / \mathrm{Si} / \mathrm{Al}\right)$ MIS Device for Optoelectronic Application" Int. J. Opt. vol. 2013 (756402), pp. $1-9,2013$.

[5] A.R. Babar, S.S. Shinde, A.V. Moholkar, C.H. Bhosale, J.H. Kim, and K.Y. Rajpure, "Sensing properties of sprayed antimony doped tin oxide thin films: Solution molarity" $J$. Alloys Compd., vol. 509(6), pp. 3108-3115, 2011.

[6] Z.Y. Banyamin, P.J. Kelly, G. West, and J. Boardman, "Electrical and Optical Properties of Fluorine Doped Tin Oxide Thin Films Prepared by Magnetron Sputtering," Coatings, vol. 4, pp. 732-746, 2014.

[7] S. Abdullahi, A.U. Moreh, B. Hamza, U. Sadiya, Z. Abdullahi, M.A. Wara, H. Kamaluddeen, M.A. Kebbe and U.F. Monsurat, "Optical Characterization of Fluorine doped Tin Oxide (FTO) thin films deposited by spray pyrolysis technique and annealed 
under Nitrogen atmosphere," International Journal of Innovation and Applied Studies, vol. 9(2) pp. 947-955, 2014.

[8] T. R. Giraldi, M. T. Escote, A. P. Maciel, E. Longo, E. R. Leite, and J. A. Varela, "Transport and sensors properties of nanostructured antimony-doped tin oxide films," Thin Solid Films, vol. 515(4), pp. 2678-2685, 2006.

[9] Dr. Khalid K. Mohammed, Ghassan H. Shakoory, and Ziyad J. Jerjees, "Study and Fabrication of High Efficiency Indium Doped $\mathrm{SnO}_{2} / \mathrm{SiO}_{2} / \mathrm{n}-\mathrm{Si}$ Solar Cells" Al-Rafidain Engineering, vol.20 (3), pp. 1-43, 2012.
[10] Aqel Mashot Jafar, Kiffah Al-Amara, Farhan Lafta Rashid and Ibrahim Kaittan Fayyadh, "Fabrication and Characterization of Fluorine-Doped Tin Oxide Transparent Conductive Nano-Films"International Journal of Innovative Research in Engineering \& Science, ISSN 2319-5665, vol. 6 (2), pp.49-58, 2013.

[11] Li Chen, Hongjun Yang, Men Tao and Weidong Zhou, "Microstructured anti-reflection surface design for the omni-directional solar cells" Proc. of SPIE vol. 7046 704608-1, 2008. 